
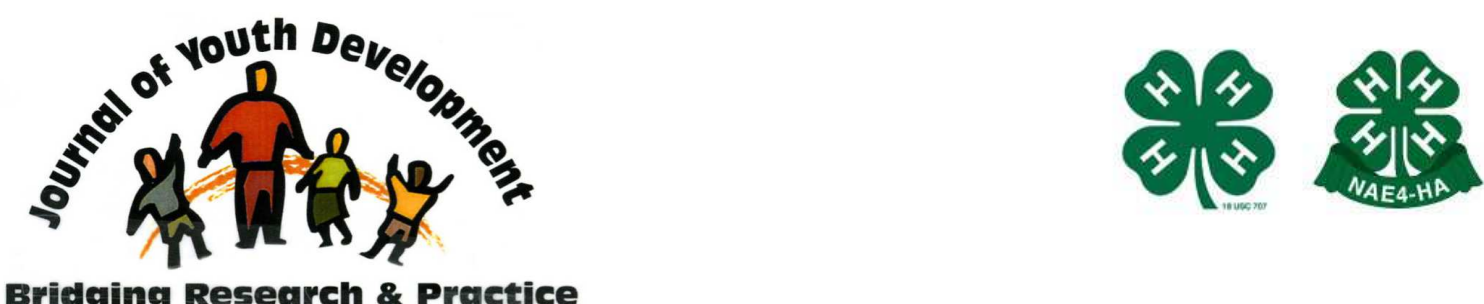

Bridging Research \& Practice

\title{
Youth Competitors Gain Benefits from Horse Show Judges' Training Program
}

\author{
Patricia A. Evans \\ Utah State University \\ Logan, Utah \\ patevans@cc.usu.edu \\ Scott McKendrick \\ Utah State University \\ Logan, Utah \\ scottm@ext.usu.edu \\ John Wesley \\ Utah State University \\ Salt Lake City, Utah \\ johnw@ext.usu.edu \\ Justen Smith \\ Utah State University \\ Farmington, Utah \\ justens@ext.usu.edu
}




\title{
JOURNAL OF YOUTH DEVELOPMENT \\ bridging research and practice

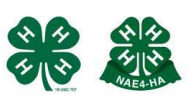

Article 080203PA002

\section{Youth Competitors Gain Benefits from Horse Show Judges' Training Program}

Patricia A. Evans, Scott McKendrick, John Wesley and Justen Smith Utah State University

\begin{abstract}
This article details how youth benefit from a horse show judges' training program. While judging is subjective, with training, judges can be more consistent in their placings, with the better horses and/or riders being placed at the top of the class. With qualified judges, youth can be more confident that they will be evaluated in a fair and consistent manner during each show all season long.
\end{abstract}

\section{Introduction}

In Utah and the Intermountain area, Open and 4-H Show managers have not had a resource of certified/qualified horse judges resulting in many show managers hiring judges without confirmed judging skills. Additionally, many judges have not had the breadth of experience to judge both English and Western events. As shows offer a greater variety of classes, the need for judges' training and knowledge of these classes, class rules and protocols also increases. Judges need to be confident and knowledgeable in their judging ability.

In response to the need for certified judges the Utah State University Equine Teaching and Extension Team organized an annual two-day Horse Show Judges' Training and Certification Program to help provide qualified judges for these growing needs in 2005.

\section{Need for More Knowledgeable 4-H Judges}

A qualified and consistent horse show judge is a benefit to a show's success while an unqualified and unprofessional judge can create friction and exhibitor dissatisfaction and even confusion among youth exhibitors (S.S. McKendrick, Utah State Director of 4-H Horse Programs, personal communication, October 18, 2007). In Utah, the 4-H Horse program expressed a need to educate judges to their program so that the youth competitors would be evaluated consistently at all events. Similar programs have been developed in other states or regions (Brady, et al., 2003; Mowrey, et al., 1991). More consistent and knowledgeable judges will 
allow the youth to strengthen their training and showmanship skills through consistent feedback from judges. With more consistent placings from show to show, youth will have a bench mark to strive for and be rewarded for a job well done. Realizing that judges are individuals, their placings will not exactly mirror another judge but it is important for the better horses/riders to be recognized and consistently placed at the top of the class.

\section{Program Purpose and Objectives}

The first goal of the Judges' Training and Certification program was to educate new and already established judges in the role of a judge for both 4-H and open horse shows. This included developing knowledgeable and confident judging techniques of a variety of typical show ring classes, including comprehension of class rules and variations that may occur by show type. The program focused on the development of an understanding of general and breed specifications for conformation and performance classes.

The second goal of the Certification program was to develop and publish a Judges' List that is readily available to $4-\mathrm{H}$ and Open show managers throughout Utah and surrounding states via hard copy or electronic format.

\section{Program Design and Delivery}

Utah State University Extension, in cooperation with the Utah 4-H Horse Program, Utah Horse Council, Pony of Americas Club, Inc/Utah Pony of the Americas Club, and local Utah State University Extension agents, organized an annual two-day program on judging procedures. This program was formatted similar to North Carolina State University's Judges' Clinic focusing on educating judges on a variety of riding styles, breeds and show rules (Mowrey, et al., 1991). The program is a regional event drawing participants from Utah, Idaho, Nevada, and Wyoming.

The first program, which was held during the spring of 2005, included lecture, video, live horse demonstrations and live horse judging. Lectures and demonstrations covered during the first day included judging ethics and the rules and scoring procedures for judging halter and performance classes. Halter classes included Arabian, POA, stock and hunter type horses while performance classes included western pleasure, western riding, reining, horsemanship, showmanship, hunt seat pleasure, hunt seat equitation, hunter over fences and equitation over fences. Information from day one covered all of the classes to be judged on the second day of the program.

Day two consisted of 22 classes with four horses in each class. Participants judged and turned in placing cards for each practice class. Each class was given an official placing by a panel consisting of two judges and a person assigning cuts. Youth judging teams and their coaches were invited and encouraged to attend on the second day during the live class evaluations to judge and listen to the official placings and cuts on each class. (a numerical/mathematical process to indicate degree of difficulty between two placings). The Hormel Scoring System was used to determine scores for each participant.

Two methods of placing were discussed and used during this program as many Utah 4-H horse shows use the Danish placing system (Utah State 4-H Rulebook, 2007) while the American system is more popular in the Open and Breed shows (AQHA Rulebook, 2007). A judging 
manual was also developed for this program so the participants would have written material to review. All participants received a certificate of completion at the conclusion of the program and were listed in the judges' booklet. Those scoring a $90 \%$ or more or that were in the top third in a category were listed as certified. They were denoted with an asterisk under the category in which they certified. Two categories in which judges were certified in were Western and Hunter. To remain on the list judges will have to attend this certification program every three years.

\section{Results and Evaluation}

Participant evaluations have been positive on the value of the Judges' Training and Certification program in improving and evaluating their judging ability. For some it was a way to evaluate their ability against their peers while others developed the skills and confidence to begin judging. Evaluations at the completion of the clinic were very positive on the knowledge and skills gained. Eight months after the 2005 clinic a follow-up impact survey was mailed out to all participants $(n=47)$ with twenty four $(51 \%)$ surveys completed and returned. This survey asked participants for information on how they had used the information and skills gained from the Certification program over the summer show months. The following information summarizes the related responses:

Question: The information you received at the Certification program in 2005 helped you to be more knowledgeable in judging horse classes.

- $23 / 24$ or $96 \%$ agreed or strongly agreed

Question: You intended to use the skills and information from the Certification to judge 4-H and Open horse shows

- $20 / 24$ or $83 \%$ responded YES.

Question: If you work with youth or adults in preparation for showing, this clinic gave you additional skills and knowledge to assist in this area.

- $17 / 24$ or $71 \%$ responded YES

Some participants did not intend to judge but to gain skills that would help the youth in their programs in developing greater horsemanship and show ring skills.

With annual judges' training on current rules and judging systems, judges will be up-to-date in their judging knowledge. This will allow youth to have a more consistent and positive judged experience which will provide the participants with incentive to work towards common and welldefined goals.

\section{Future Plans}

Further program development will continue with feedback from both 4- $\mathrm{H}$ and Open show judges and managers. Evaluations from show managers will be sought to determine if judges from the list have satisfied their needs. A follow-up evaluation from trainers that work with youth and 4-H leaders will be used to evaluate usefulness to youth programs. As new needs arise, this program will continue to evolve to meet those needs. This same type of judges' certification school could be applied to Junior Livestock programs in Utah, judges of any and all 4-H fair 
entries (gardening, clothing, foods, etc.). By creating competent judges, the satisfaction of the judging process increases and exhibitors are confident that they will receive consistent judging.

\section{References}

American Quarter Horse Association. (2007). AQHA Handbook of Rules and Regulations (p. 108). [On-line]. Available at:

http://www.aqha.com/association/registration/pdf/showrules 07.pdf

Brady, C., Griffin, A., \& Kline, R. (2003). Coordinating and Conducting a Multi-State 4-H Horse and Pony Judges' School. Journal of Extension [On-line], 41(3) Available at:

http://www.joe.org/joe/2003june/iw2.shtml

Mowrey, R.A., \& Barnett, D.T. (1991). North Carolina Open Horse Show Judges' Clinic. 12th Equine Nutrition and Physiology Symposium. Alberta, Canada.

Utah State 4-H Horse Council. (2007). Utah State Horsemanship Contest Rules (p.3). Utah State 4-H. [On-line]. Available at:

http://utah4hhorse.org/files/uploads/Horse\%20Rule\%20Book\%20042707c.pdf

(C) Copyright of Journal of Youth Development $\sim$ Bridging Research and Practice. Content may not be copied or emailed to multiple sites or posted to a listserv without copyright holder's express written permission. Contact Editor at: patricia.dawson@oregonstate.edu for details. However, users may print, download or email articles for individual use.

ISSN 2325-4009 (Print); ISSN 2325-4017 (Online) 